Case for Teaching

\title{
Pandemic Fightsin a Network! COVID-19 Challenges in Northeast Brazil
}

\author{
Pandemia se Combate em Rede! Desafios da COVID-19 no Nordeste do \\ Brasil
}

Discipline: Public Management

Subject: Public Governance

Industry: Government

Geography: Ceará/Brazil

\author{
Raphael Jesus Campos de Andrade ${ }^{10}$ \\ José Milton de Sousa-Filho ${ }^{2}$ \\ Fátima Evaneide Barbosa de Almeida ${ }^{30}$ \\ Samuel Façanha Câmara ${ }^{4}$
}

\section{INTRODUCTION}

Northeast, 11 March 2020.

"The World Health Organization (WHO) said on Wednesday that the COVID-19 outbreak could already be considered a pandemic. The new coronavirus, as it became known, has infected more than 110,000 people worldwide since the end of December. According to Tedros Adhanom Ghebreyesus, director of WHO, the outbreak is being evaluated at all times and there is great concern about the virus spreading at alarming levels as well as the inaction of countries and institutions. The disease first emerged in the city of Wuhan, China, at the end of last year, but has since spread worldwide; Italy, Iran, and South Korea are especially affected, but all continents, with the exception of Antarctica, have already reported cases of infections," said a radio reporter.

Even with the disease widespread throughout Europe and several other parts of the world and having arrived in Brazil about two weeks ago, Miguel Bastos, manager of innovation manager of Sistema Indústria, really did not suspect that in a very short time his daily tasks would cease to be a priority and that his institutional challenges would be completely related to combating COVID-19.

1. Universidade Federal do Ceará, Fortaleza, CE, Brazil.

2. Universidade de Fortaleza, Programa de Pós-graduação em Administração, Fortaleza, CE, Brazil.

3. Fundação Cearense de Apoio ao Desenvolvimento Científico e Tecnológico, Fortaleza, CE, Brazil.

4. Universidade Estadual do Ceará, Programa de Pós-graduação em Administração, Fortaleza, CE, Brazil.

Cite as: Andrade, R. J. C., Sousa-Filho, J. M., Almeida, F. E. B., \& Câmara, S. F. (2021). Pandemic fights in a network! COVID-19 challenges in northeast Brazil. Revista de Administração Contemporânea, 25(spe), e200256. https://doi.org/10.1590/1982-7849rac2021200256.en

$\sum_{-1}^{1}$

JEL Code: A20, 13, N16.

Editor-in-chief: Wesley Mendes-da-Silva (Fundação Getulio Vargas, EAESP, Brazill) Associate Editor: Paula C. P. de S. Chimenti (Universidade Federal do Rio de Janeiro, COPPEAD, Brazil) Guest Editor: Leonardo Marques (Universidade Federal do Rio de Janeiro, COPPEAD, Brazill) (c) Reviewers: Kenyth Alves de Freitas (Fundação Getulio Vargas, EAESP, Brazil) One of the reviewers chose not to disclose his/her identity.

Peer Review Report: The Peer Review Report is available at this external URL.

Received: July 19, 2020 Last version received: November 17, 2020 Accepted: November 27, 2020 
Sistema Indústria represents the industrial sector of the Northeast region, operating since 1950 and having 40 associated employer unions. It consists of the following entities: Northeast Industrial Training Service (Sefin), Northeast Industry Health Service (Sesano), and Institute for Business and Career Development (Ideca). The actuation of Sistema Indústria consists of six strategic axes: basic education leading to the improvement of educational quality in the Northeast, professional and higher education focused on the future of work in industry, industrial modernization intensive in innovation, innovation management solutions for the productive sector through agile processes, safety and health in Industry integrated into work to reduce risks and costs, internationalize the Industry and promote investments.

Just five minutes late, Miguel entered the meeting room. Waiting there were: Renato Amarante, president of Sistema Indústria, and his team - Simplício Neto, director of innovation; Pedro Henrique França, director of technology; Tayrone Sales, technology manager; and José Armani, production supervisor.

"... I would like, then, contribution from all of you regarding what we should do...," said Renato.

"President, we have no option but to close everything..."

"Close everything, Simplício?! Are you crazy?!"

"Unfortunately, Pedro, Simplício had the courage to face the facts right away... From what we have been monitoring with the regional government, the situation really is very serious..."

"Have we really reached this point, president? What is the government's position?

"Yes, Pedro... The projections of the Regional Crisis Committee are not encouraging... The tendency is to close practically all economic activities, with the exception of essential services... A decree in this sense should be published, establishing the terms..."

"I suggest setting up a contingency plan, President Renato, with measures that will allow us to continue working remotely... We need to strengthen the relationship with our customers, strengthen support for the industries..."

"Good suggestion, Miguel! Compensating for your usual delay... very good!"

“Thank you very much, president!" said Miguel with his head down, avoiding eye contact with his colleagues.

"So, let's get to work, everyone! You have one week to give all the conditions to our employees so that they can continue with their activities from home. We will follow the experience to see what happens...," announced Renato, afraid of his decision and worried about what was yet to come.

\section{EMERGENCY ACTIONS}

The pandemic had crept its way to Northeast Brazil. Overnight, the fearsome reality of thousands of people infected and hundreds of daily deaths collapsing the health system and funeral establishments in Italy and Spain now seemed to be overflowing from the TV (or perhaps from the screen of a catastrophe movie) into the daily lives of Northeasterners. In this initial context of astonishment and uncertainty, dozens of public and private institutions began to carry out, in an improvised and uncoordinated way, several emergency actions to mitigate and combat the dissemination of COVID-19 throughout the Northeast.

First, a group of project, process, and innovation management professionals, led by Sandoval Ampere, a renowned local project manager, created a civil society movement to save lives, forming three working groups composed of volunteers. The first group was responsible for sizing up the needs of the health system for scarce products on the market and what was necessary for the provision of medical services, as well as for carrying out requirements analyses (materials, quantities, production methods, etc.) for the prototyping and production of these products. The second group committed to the writing of projects to raise funds along with economic grant edicts to combat COVID-19 launched by funding agencies from all over Brazil. The third group was configured as a Communication and Marketing area of the movement, which was renamed Movimento Respira Nordeste ("Breathe Northeast Movement"), structuring its visual identity, its profiles on social networks, and its communication materials in general.

Quickly, dozens of professionals from the most diverse areas of knowledge, entrepreneurs from different sectors, and volunteers of all types joined the movement, interested in contributing with resources, skills, cash donations, etc. The tireless work of Sandoval, leader of the movement, was crucial to the mobilization of so many highly qualified and dedicated volunteers.

Among the various volunteers sensitized by Sandoval, several experts in the technology area of the Sistema Indústria have stood out in the working groups, with assertive contributions on how to develop certain solutions. Due to the strong participation of the technical staff, little by little the management team and the Technology and Innovation Boards of the Sistema Indústria, led, respectively, by Pedro Henrique França and Simplício Neto, informally joined the Movimento Respira Nordeste, which would result in joint 
and specific actions of developing solutions, manufacturing products, and maintaining equipment aimed at relieving the crisis.

In parallel, and disconnected from these initiatives, Renato, president of Sistema Indústria, mobilized the business sector to allocate resources for the improvement of working conditions and infrastructure of the regional health system, raising in a short time more than 10 million Brazilian reais that would be directly applied to actions that combat COVID-19 of Sistema Indústria itself.

Dozens of other institutions followed their own course of emergency response to the health crisis in isolation, which involved actions such as: composition of proposals and protocols for economic recovery, solidarity campaigns, loans for $3 \mathrm{D}$ printers for the manufacture of PPE, free remote consultancies and advisories for companies on ways to access credit lines and other topics of interest, development of artificial intelligence algorithms for the diagnosis and monitoring of the disease, among many other initiatives with different levels of maturity and impact.

Nevertheless, all of these institutional efforts initially faced at least two major common challenges. First, the lack of integration between the initiatives, given the involvement of a very large number of people, a flow of information that is very intense and difficult to coordinate and the lack of experience curve on such complex and fraught themes with uncertainties. Secondly, all initiatives began to live with doubts about what actually needed to be acquired and/ or produced, since the demands came mainly from public authorities - from the Regional Crisis Committee of the government, the regional health agencies and their teams (urgent care centers, hospitals, etc.).

At this moment, Miguel, our protagonist who was linked to Sistema Indústria, stands out, having been active in the area of network innovation and, mainly, had a recent experience about industrial disasters. These characteristics qualified Miguel, who would become the centerpiece in this context of uncoordinated initiatives...

\section{COORDINATION AND LEADERSHIP}

For many years, Miguel was quite integrated with the innovation initiatives of the Northeastern institutions, having even participated actively in the construction of a good part of them. With the advent of the pandemic, he followed the responses of dozens of institutions at a medium distance, all of which were internally stunned and externally uncoordinated. As innovation manager of Sistema Indústria, he was responsible for providing innovative solutions to combat COVID-19 for the health system and the productive sector. Additionally, he had a seat on the Superior Council of the Northeast Research Support Foundation (Fapne), and because of that, he received a call from Jairo Sousa, director of Fapne.

"Hello, Miguel? This is Jairo... Can you talk?"

"Hi, Jairo. How are you? Yes, I can..."

"We need your help... We have received several demands from the regional health system and we need to present a structured response... Things are very complicated in the government... According to Xerxes Filho, who works in the regional government and is responsible for the epidemiological indicators, the health system is moving at a rapid pace toward collapse!"

"Did you say demands from the healthcare system?!" Miguel replied enthusiastically.

"Exactly! Every day the health secretary calls... the head of the Civil House, the secretary of science and technology... even the governor, who is very concerned about the purchase of medical and hospital equipment and personal protection that may take a long time to arrive from China! Márcio Albuquerque, superintendent of the Regional Health Institute... You know him... also sought us out for support... It seems that the Institute has just completed an inventory of mechanical ventilators in the Northeast and discovered that a large part is completely obsolete or in need of maintenance..."

"Jairo, you have got to be kidding... Ever since this social isolation began, I have watched dozens of institutions mobilize in every way to solve problems in the health system that do not present themselves in a clear and structured way... No one has objective answers to basic questions: What equipment is missing? How many? For which hospitals? And you come to me saying that the Regional Crisis Committee and other stakeholders are knocking on your door every day, clamoring for solutions? How wonderful!!! We can begin to direct the efforts then!"

"Excellent, Miguel! I knew I would find a way by talking to you... What do you think of elaborating an innovation project for Fapne, aligning these initiatives that you know?"

It was then that the actions finally started to integrate... Miguel brought together leaders from Fapne and Sistema Indústria around the theme of combating the pandemic. In effect, Fapne began to learn about and support the efforts of Sistema Indústria, making connections with the organs of the health system and facilitating the survey of requirements for the products to be developed.

Miguel began to lead the team of the Sistema Indústria projects office, with the perspective of drafting a project for Fapne aimed at the maintenance of obsolete 
mechanical ventilators from the regional government, for the emergency development of new low-cost functional ventilators and for the large-scale manufacturing of different personal protective equipment. The project was completed in just two days and involved not only Sistema Indústria, but also several institutions participating in the promotion of relief measures, such as the Federal University of Northeast (UFN), the Regional Prototyping Association (APR), and the Movimento Respira Nordeste itself, even though it is not yet legally constituted. In less than a week, the project was evaluated and approved by Fapne, providing, in the subsequent 30 days, the following partial results:

1. Sistema Indústria started to produce the first prototypes of low-cost pulmonary ventilators and several large-scale personal protective equipment;

2. The administrative staff of Sistema Indústria was mobilized to provide proper support to the project, making purchases of supplies and raw materials and organizing the logistics;

3. The Health Secretariat of the regional government began validating the prototypes of mechanical ventilators that were developed;

4. The industrial maintenance unit of Sistema Indústria was established by the governor as the official maintenance center for mechanical ventilators of the regional government;

5. Private companies joined Sistema Indústria as manufacturers and donors of personal protective equipment, maximizing installed production capacity;

6. The Movimento Respira Nordeste gained prominence in the national media;

7. The top management of Sistema Indústria authorized the use of its brand as a supporter of the Movimento Respira Nordeste;

8. Other sectors of Sistema Indústria, such as Operations Management, Planning Management and Technology Management, at the request of the presidency, began to have knowledge of the initiatives, engage in the project and demand internal alignment for effective contribution;

9. The Movimento Respira Nordeste received a donation of a large amount of acetate from an entrepreneur and sent the material to Sistema Indústria to use as raw material in its process of manufacturing personal protective equipment.

Figure 1 shows the coordination and leadership network formed to combat COVID-19.

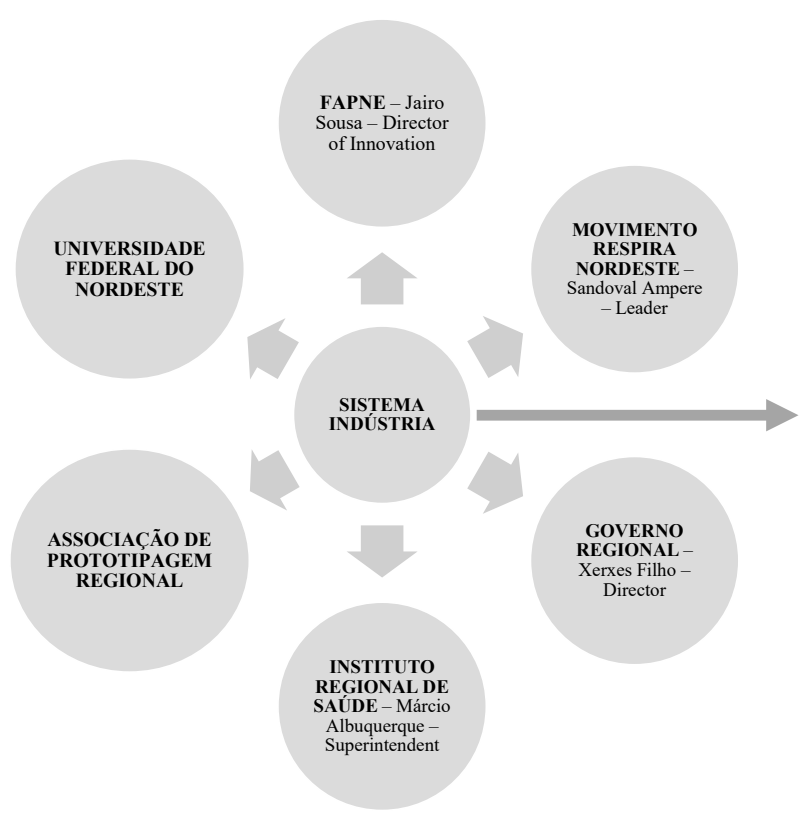

\section{SISTEMA INDÚSTRIA}

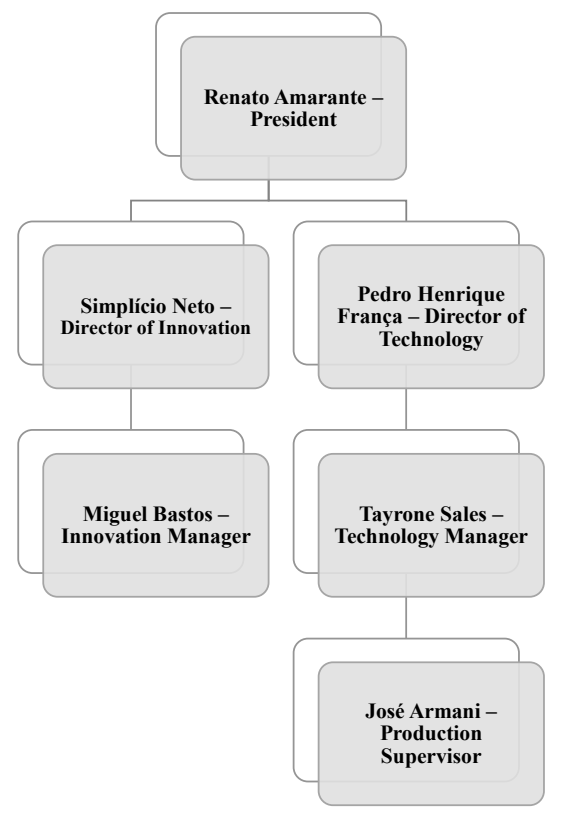

Figure 1. Coordination and leadership network.

Source: Elaborated by the authors. 


\section{INEFFICIENCIES IN THE COOPERATION PROCESS IN THE NETWORK}

"So, Miguel, have you decided to leave the good life of video conferencing and observe who is working?"

"Yes, Armani... I need to stretch my legs... What about you? What is going on where you are?"

"The usual... supervising the production and delivering results..."

"Joking aside, the production process you set up is really excellent! The 'Sistema Indústria' standard! Congratulations!"

"Thanks, Miguel! The team is very competent and very integrated! We would not have gotten where we are without the participation of everyone..."

"As for collaboration with partners, I also see that we have many achievements... but I think we can improve a lot of things... I made a report with a list of some points and would like to know your thoughts..."

"Let me see it..."

Miguel handed his tablet to Armani, production supervisor of Sistema Indústria, who took off his glasses, which were fogged due to his breathing being muffled by the mask, to read the following items carefully:

1. Taking inventory of pending mechanical ventilators from the state $-2,000$ mechanical ventilators have been promised and, so far, 30 of them have been delivered;

2. Sizing up the demands of public health equipment and structuring product distribution logistics the regional government, in fact, does not properly know its own structure, sizing up its demands very precariously;

3. Deepening of product requirements and validation of prototypes on the part health agencies - the knowledge on the subject is completely fragmented, making work difficult; specialists in the regional health system are, of course, doctors, nurses, and physiotherapists, completely unaware of the engineering requirements for the manufacturing of medical and hospital equipment;

4. Intellectual property rights - no one has defined anything yet about the appropriation of any gains from the solutions being developed;
5. Governance structure - the actions of cooperation were consolidated due to the deliveries and accountability of an innovation project, but the proposing institutions have no agreement on the decision structures;

6. Long-term knowledge and planning management model - at all times, problems arose, challenging teams to find new solutions, generating a living laboratory without any type of registration or perspective of creating long-term organizational skills.

Armani was very involved with the operations and, understandably, he had not thought about any of those things yet. He congratulated Miguel in a disconcerted manner and suggested that he discuss the matter with the directors of Sistema Indústria so that they could outline strategies for strengthening interinstitutional cooperation.

"Without a doubt, Armani! That is exactly what I am going to do, but I wanted to hear your opinion first precisely because I am involved with the day-to-day challenges... I needed to validate my perceptions... Thank you very much for your help!"

\section{DILEMMAS OF MIGUEL}

Everyone involved had the distinct feeling that they were working much more than usual, both those on the front line and support teams working on the home office model. However, the achievements obtained were very rewarding and clearly strengthened the motivation and commitment of employees and volunteers. Miguel, however, sought to identify the flaws in the collaborative process and the emerging challenges to be faced.

Miguel kept thinking... How to effectively manage a network of institutions to deal with challenges that go beyond the organizational boundaries of Sistema Indústria? How to capture the demands of the regional health system quickly and distribute information in an assertive manner to the appropriate stakeholders? Given the impossibility of using traditional mechanisms of command and organizational control, what could Sistema Indústria do to align different actors around the same purpose of combating COVID-19? Miguel dwelled on these questions and how he could give responses to each one. 


\section{Teaching Notes}

\section{ABSTRACT}

With the occurrence of the COVID-19 pandemic in 2020, it became imperative to adopt emergency measures to prevent a crisis in the health system in northeastern Brazil. In this context, Miguel Bastos, manager of Sistema Indústria, a class entity in the northeastern industrial sector, dedicated all his efforts to coordinate an emerging network of institutions involved in research, development, innovation, manufacturing, and maintenance of products demanded by a health system. Thus, this teaching case aims to allow students to understand the context of a cooperation network created to meet the needs of the health sector in combating the pandemic of COVID-19. Given the difficulties inherent in a leadership process involving seven different institutions, how should the protagonist organize this network to meet the expected demands? The case has as target audience undergraduate Business Administration students, as well as lato sensu graduate courses, in subjects such as Business Strategy, Cooperation Networks, Public-Private Partnerships, among others that address the themes proposed in the present case. It is noteworthy that authors collected data from participant observation, secondary data, and interviews. The characters are real, but the names are fictitious.

Keywords: network innovation; collaborative governance; crisis and emergency management; COVID-19 pandemic.

\section{Collection sources and methods}

The present teaching case is based on facts. Data were collected from direct observation, participant observation, secondary data, and interviews with the characters. The characters are real, but the names have been changed so that their identities are preserved.

\section{Educational objectives and recommended use}

This case aims to enable students to understand the context of a cooperation network created to meet the needs of the health sector in combating the COVID-19 pandemic. The proposal is to have the students analyze the data and the context, put themselves in the shoes of the protagonist, and discuss the best alternative solutions to the dilemma that is posed. Characteristics such as creativity and critical thinking are encouraged for decision-making in this teaching case.

\section{RESUMO}

Com a ocorrência da pandemia da COVID-19 em 2020, tornou-se imperiosa a adoção de medidas emergenciais no sentido de evitar uma crise do sistema de saúde no nordeste do Brasil. Nesse contexto, Miguel Bastos, gerente do Sistema Indústria, entidade de classe do setor industrial nordestino, dedicou todos os seus esforços para coordenar uma rede emergente de instituiçóes envolvidas em processos de pesquisa, desenvolvimento, inovação, fabricação e manutenção de produtos demandados pelo sistema de saúde. Dessa forma, este caso de ensino tem como objetivo permitir que os alunos entendam o contexto de uma rede de cooperaçáo criada para suprir as necessidades do setor de saúde no combate à pandemia de COVID-19. Face às dificuldades inerentes a um processo de liderança envolvendo sete instituiçóes diferentes, como o protagonista deve organizar essa rede para atender às demandas previstas? O caso tem como públicos-alvo os alunos de Graduação em Administração, bem como de cursos de pós-graduação lato sensu, em disciplinas como Estratégia Empresarial, Redes de Cooperação, Parcerias Público-Privadas, dentre outras que abordem os temas propostos no presente caso. Ressalta-se que os dados foram coletados a partir de observação participante, dados secundários e entrevistas. Os personagens são reais, mas os nomes são fictícios.

Palavras-chave: inovação em rede; governança colaborativa; gestão de crises e emergências; pandemia da COVID-19.

Along these lines, the case also has the following educational objectives:

1. Comprehend the challenges of interinstitutional management in a context of crises and emergencies;

2. Understand the initial conditions for collaboration as well as the role of leadership in the collaborative process;

3. Learn about the construction and progress of the collaboration process in a crisis context.

From the point of view of the recommended use, the case was developed to promote the exploration of concepts related to the areas of Strategy, Cooperation Networks, Network Governance, and Public Management. Thus, the case can be applied to undergraduate courses in Business Administration as well as lato sensu graduate courses (specializations and MBAs), in disciplines such as Business Strategy, Cooperation Networks, and PublicPrivate Partnerships, among others that address the themes proposed in the present case. 


\section{Lesson plan}

The case can be applied in a traditional session lasting two hours/class. Following are application recommendations before the class in which the case will be used: (a) divide the class into groups of three to five students; (b) make the case available to the students in advance, with sufficient time for reading and preparing responses; (c) make the questions available for discussion; (d) recommend that students individually answer questions before the class.
At the time of the class, during the application of the case, the teacher must guide the teams to meet and discuss individual responses, seeking a solution (or solutions) that represent(s) the understanding of its members. Next, the teams should meet in plenary to present and discuss their analysis and solutions with the entire room. The teacher must conduct this entire process and, at the end, conclude the class, presenting and connecting the theory used to support the teaching case.

In order to support the teacher in conducting the case in the classroom, it is suggested to follow the lesson plan presented in Table 1.

Table 1. Suggested lesson plan.

\begin{tabular}{lc}
\hline Activity & Duration (minutes) \\
\hline General presentation of the case and detailed educational objectives, conducted by the teacher. & 10 \\
In groups, debate the case considering its events and context, addressing the issues that are described in the section "Questions for & 40 \\
discussion." & 30 \\
Plenary presentation and debate about the answers, analyses, and solutions proposed by the groups. & 20 \\
General conclusion of the case, conducted by the teacher. & 100 \\
\hline Total
\end{tabular}

Note. Source: Elaborated by the authors.

\section{Questions for discussion}

1. Interinstitutional management: How did interinstitutional management occur in terms of mobilization, organizational agreements, conducting interactions, strategies, and goals?

2. Initial conditions for collaboration: What were the initial conditions for collaboration, especially in aspects related to asymmetries of power, resources and knowledge, and confidence building?

3. Facilitating leadership: What is the role of leadership in the process of building collaboration, as well as for the results that have been achieved?

4. Institutional design: How did institutional design affect the collaboration process? What is the role of each institution in this process, as well as of mutual institutional influences?

5. Collaborative processes: How was collaboration built? Comment on aspects related to building trust, commitment, shared understanding, among others.

\section{Analysis of the case supported by the literature}

The questions for discussion were established around the educational and learning objectives and according to categories of analysis belonging to the collaborative governance literature - a type of governance that brings together public and private actors in decision-making forums oriented toward consensus. In this way, they can use particular processes in different ways to establish laws and rules for the provision of collective gains (Ansell \& Gash, 2008).

In this context, it is understood that the quality of social relations in a locality (in this case, the Northeast) has an important effect on social life and business performance and depends on some essential factors, such as a multitude of civic associations, a high level of interaction between social groups, coalitions beyond individual interests, a strong sense of common goals, and the guarantee of property rights (Healey, 1995; North \& Thomas, 1973).

Therefore, in order to be effective, collaborative governance must result from a plurality of interactions between entities in the public and private spheres (Klijn, 2014). But it is unlikely that the parties, however capable they are, will collaborate spontaneously, without a manager promoting and ensuring the integrity of the consensusbuilding process itself. From a network or interinstitutional perspective, policymaking and implementation is a complex process. Interesting results for the actors involved do not come immediately, but need to be managed and coordinated carefully.

Therefore, the following aspects stand out as crucial elements of collaborative governance: interinstitutional 
management, initial conditions for collaboration, facilitating leadership, institutional design, and collaborative processes, which, together, turn to reach results. Based on these elements, the following questions for discussion are finally proposed, as well as respective proposals for answers:

1. Interinstitutional management: How did interinstitutional management occur in terms of mobilization, organizational agreements, conducting interactions, strategies, and goals?

In short, the role of the manager from an interinstitutional network perspective is equivalent to that of a mediator, of a process manager. This is because network management is, in essence, an interinstitutional activity. It is clear, however, that if the network manager is to achieve important results, a variety of different strategies is required (Klijn, 2014).

Collaborative governance, therefore, is characterized as an interinstitutional management process, whose main activities, which differ significantly from intraorganizational management practices, constitute strategies aimed at managing the network itself and its interactions, as shown in Table 2.

Table 2. Network governance strategies.

\begin{tabular}{lll}
\hline \multicolumn{1}{c|}{ Strategies } & \multicolumn{1}{c}{ Interaction management } & \multicolumn{1}{c}{ Network management } \\
\hline Activation of actors and resources & $\begin{array}{l}\text { Selective activation, resource mobilization, } \\
\text { stabilization, deactivation of actors and } \\
\text { resources, initiation of new series of interactions, } \\
\text { coalition building }\end{array}$ & $\begin{array}{l}\text { Network activation, changing network } \\
\text { composition, changing position of actors, } \\
\text { changing resources }\end{array}$ \\
Strategies to achieve goals & $\begin{array}{l}\text { Search for congruence of goals, creation } \\
\text { of variations in solutions, influence (and } \\
\text { explanation) of perception, management and } \\
\text { collec-tion of information and research }\end{array}$ & $\begin{array}{l}\text { Redefining perceptions, changing decision- } \\
\text { making roles in networks, permanently } \\
\text { changing the flow of information }\end{array}$ \\
Organizational agreements & $\begin{array}{l}\text { Creation of new organizational agreements } \\
\text { (councils, project organizations, etc.) }\end{array}$ & $\begin{array}{l}\text { Creation of permanent organizational } \\
\text { constructions }\end{array}$ \\
Conducting interactions & $\begin{array}{l}\text { Meditation, intermediation, intervention by } \\
\text { the process manager, removing obstacles to } \\
\text { cooperation, creating incentives for cooperation }\end{array}$ & $\begin{array}{l}\text { Change of rules for conflict regulation, for } \\
\text { information flow, change of payment rules or } \\
\text { professional codes }\end{array}$ \\
\hline
\end{tabular}

Note. Source: Adapted from Klijn (2005).

Miguel faced the dilemma of interinstitutional management by defining the role of each of the actors in the network. He established an effective and fast communication through the creation of a group on WhatsApp, in which everyone had the opportunity to present their difficulties and needs. Furthermore, visits to the workplace and closer contact with the actors were important to strengthen communication and interactions between the teams. In frequent meetings with Jairo, Miguel constantly aligned the objectives and goals required by the other actors and institutions participating in the network.

2. Initial conditions for collaboration: What were the initial conditions for collaboration, especially in aspects related to asymmetries of power, resources and knowledge, and confidence building?

The initial conditions for collaboration involve imbalances in resources, knowledge and power, antecedents of cooperation or conflict, and levels of trust between the parties involved and will encourage or restrict participation.
If there are significant imbalances, effective governance requires a strategy to strengthen the weakest social groups.

The management experience of Miguel at Sistema Indústria, along with his position on the Fapne Superior Council, was fundamental in facilitating the coordination of the network. In a way, there was already a relationship between the institutions and actors in the network, such as participation in partnership projects, but, at most, involving two institutions. The positive point was that there was no conflict between the actors and the institutions, but, at the same time, there was no experience curve with collaborative work, much less in facing a problem of a pandemic on this scale.

3. Facilitating leadership: What is the role of leadership in the process of building collaboration, as well as for the results that have been achieved?

The facilitating leadership coincides with the interinstitutional manager previously presented and has the 
role of educating and including weaker groups, as well as giving a meaningful voice to the participants, encouraging them to listen to each other. In the absence of other elements of effective governance, facilitative leadership becomes more crucial. On the other hand, collaboration can be seriously affected in the absence of a leader capable of mediating the processes of collective construction.

The definition of the leader was crucial to the success of the project.

It was important to have a manager with knowledge of the processes of each institution and also with an appropriate interpersonal relationship, with good leadership and who developed empathy with the teams well. In this sense, choosing Miguel was a factor that contributed to the construction of a collaborative team that was willing to achieve the set goals.

4. Institutional design: How did institutional design affect the collaboration process? What is the role of each institution in this process, as well as of mutual institutional influences?

The institutional design, in turn, refers to the formalization of governance structures, the clear definition of roles, protocols, and rules that are crucial for transparency and the procedural legitimacy of collaboration. If there are alternative and unilateral decision-making spaces, there will only be collaboration if the parties are highly interdependent.

The elaboration of the project by Miguel, in collaboration with the various participants in the network, contributed to the formalization of a governance structure, since the roles and responsibilities of each institution were defined and each was aware of their mutual influences.

5. Collaborative processes: How was collaboration built? Comment on aspects related to building trust, commitment, shared understanding, among others.

Finally, collaborative processes involve face-to-face dialogue, building trust and commitment between the parties and a shared understanding of what can be achieved together. Nevertheless, the parties will not continue to spend their time on collaboration if at least small victories are not achieved.
The project undertaken by the actors required a greater effort than usual. All were involved in purposes that brought an extremely motivating element: to bring relief to people affected by the disease or even to save lives. The collaboration was built mainly around this purpose and, in line with the personal characteristics of the leadership and of each participating actor, resulted in achievements previously not imagined by each institution in isolation.

Once these elements are brought together, it becomes possible to avoid high costs of policy formulation, expand democratic participation, involve adversaries in productive discussions, establish fruitful relationships between stakeholders, and develop sophisticated ways of learning and problem solving.

It is assumed, therefore, that collaborative governance is a potentially effective means of creating an enabling environment for the emergence of leading companies and a visionary state, which may come to decide on policies of collective interest.

The results collaboratively obtained by the teams under the leadership of Miguel demonstrate how important it is to adopt a model of collaborative governance and the development of collaborative processes to achieve the desired goals.

\section{Outcome}

After three months of social isolation, the results obtained with the innovation project subsidized by Fapne and, mainly, with the voluntary work of dozens of institutions and thousands of people were invaluable with regard to the generation of relief related to the health crisis. More than 100 mechanical ventilators from the regional government were recovered and could be used to care for at least 300 patients with COVID-19. Tens of thousands of personal protective equipment were produced by Sistema Indústria and its partners and donated to public and private hospitals throughout the regional health system. Moreover, Sistema Indústria, in partnership with the Regional Health Institute and UFN, really managed to develop a low-cost, scalable, and non-invasive mechanical ventilator, standing out as a provider of technology and innovation. 


\section{REFERENCES}

Ansell, C., \& Gash,A. (2008). Collaborative governance in theory and practice. Journal of public administration research and theory, 18(4), 543-571. https://doi.org/10.1093/jopart/mum032

Healey, P. (1995). The institutional challenge for sustainable urban regeneration. Cities, 12(4), 221-230. https://doi.org/10.1016/0264-2751(95)00043-L

Klijn, E. H. (2005). Networks and inter-organizational management: Challenging steering, evaluation and the role of public actors in public management. In E. Ferlie, L. Lynn, \& C. Pollitt (Orgs.). The Oxford Handbook of Public Management (pp. 275-281). Oxford: Oxford University Press.

\section{Authorship}

\section{Raphael Jesus Campos de Andrade*}

Universidade Federal do Ceará

Av. da Universidade, no 2486, Benfica, CEP 60020-180, Fortaleza, CE, Brazil

E-mail address: raphaeldj.campos@gmail.com

(D) https://orcid.org/0000-0002-6062-2931

\section{José Milton de Sousa-Filho}

Universidade de Fortaleza, Programa de Pós-graduação em Administração

Av. Washington Soares, no 1321, Edson Queiroz, 60.811-905, Fortaleza, CE, Brazil

E-mail address: miltonsousa@unifor.br

(D) https://orcid.org/0000-0002-3078-3179

\section{Fátima Evaneide Barbosa de Almeida}

Fundação Cearense de Apoio ao Desenvolvimento Científico e Tecnológico

Av. Oliveira Paiva, no 941, Cidade Dos Funcionários, 60.822-130,

Fortaleza, CE, Brazil

E-mail address: fatimaevaneide.almeida@gmail.com

(D) https://orcid.org/0000-0003-3751-7890

\section{Samuel Façanha Câmara*}

Universidade Estadual do Ceará, Programa de Pós-graduação em Administração

Av. Dr. Silas Munguba, no 1700, Itaperi, 60740-000, Fortaleza, CE, Brazil

E-mail address: samuel.camara@uece.br

(D) https://orcid.org/0000-0002-8333-6997

* Corresponding Author

\section{Funding}

The authors reported that there is no financial support for the research in this article.
Klijn, E. H. (2014). Redes de política e implementação: Gerenciando interaçóes complexas (pp. 108-133). In S. Cropper, M. Ebers, C. Huxham, \& Ring, P. S. Handbook de relaçóes interorganizacionais da Oxford. Porto Alegre: Bookman.

North, D. C., \& Thomas, R. P. (1973). The rise of the western world: A new economic history. Cambridge: Cambridge University Press.

\section{Authors' Contributions}

$1^{\text {st }}$ author: conceituação (liderança); metodologia (liderança); supervisão (liderança); escrita - rascunho original (liderança); escrita - revisão e edição (igual).

$2^{\text {nd }}$ author: conceituação (igual); metodologia (igual); validaçáo (liderança); escrita - rascunho original (igual); escrita - revisão e edição (liderança).

$3^{\text {rd }}$ author: conceituação (igual); metodologia (igual); escrita - rascunho original (igual); escrita - revisão e edição (igual).

$4^{\text {th }}$ author: conceituação (igual); metodologia (igual); escrita - rascunho original (igual); escrita - revisão e edição (igual).

\section{Conflict of Interests}

The authors have stated that there is no conflict of interest.

\section{Copyrights}

RAC owns the copyright to this content.

\section{Plagiarism Check}

The RAC maintains the practice of submitting all documents approved for publication to the plagiarism check, using specific tools, e.g.: iThenticate.

\section{Peer Review Method}

This content was evaluated using the double-blind peer review process. The disclosure of the reviewers' information on the first page, as well as the Peer Review Report, is made only after concluding the evaluation process, and with the voluntary consent of the respective reviewers and authors.

\section{Data Availability}

RAC encourages data sharing but, in compliance with ethical principles, it does not demand the disclosure of any means of identifying research subjects, preserving the privacy of research subjects. The practice of open data is to enable the reproducibility of results, and to ensure the unrestricted transparency of the results of the published research, without requiring the identity of research subjects. 